\title{
Peroxisomal Multifunctional Enzyme Type 2
}

National Cancer Institute

\section{Source}

National Cancer Institute. Peroxisomal Multifunctional Enzyme Type 2. NCI Thesaurus.

Code C114366.

Peroxisomal multifunctional enzyme type 2 (736 aa, $~ 80 \mathrm{kDa}$ ) is encoded by the human HSD17B4 gene. This protein is involved in the peroxisomal beta-oxidation pathway for fatty acids. 